TITLE PAGE

\title{
Standardized MET value underestimates the energy cost of treadmill running in men
}

Running head: Metabolic equivalents in exercise prescription

Helouane M. Ázara ${ }^{1}$, Paulo T.V. Farinatti2,3,4, Adrian W. Midgley ${ }^{5}$, Fabrício Vasconcellos ${ }^{2,3}$, Patrícia Vigário $^{1}$, and Felipe A. Cunha ${ }^{1,2,3}$

1) Post-Graduate Program in Rehabilitation Sciences, Augusto Motta University Center (UNISUAM), Rio de Janeiro, Brazil.

2) Post-Graduate Program in Exercise Science and Sports, University of Rio de Janeiro State, Rio de Janeiro, Brazil.

3) Laboratory of Physical Activity and Health Promotion, University of Rio de Janeiro State, Rio de Janeiro, Brazil.

4) Post-Graduate Program in Physical Activity Sciences, Salgado de Oliveira University, Niterói, Rio de Janeiro, Brazil.

5) Department of Sport and Physical Activity, Edge Hill University, Ormskirk, Lancashire, England

\section{Address for correspondence:}

Felipe A. Cunha, PhD. Rehabilitation Sciences, Augusto Motta University Center, UNISUAM. Praça das Nações 34, 3ํandar, Bonsucesso, Rio de Janeiro, RJ, Brazil. CEP 21041-010; Phone: +55 (21) 3882-9797 ramal 2012. E-mail: felipeac@globo.com

Acknowledgements: This research was partially supported by grants from the Carlos Chagas Filho Foundation for the Research Support in Rio de Janeiro State and Brazilian Council for the Technological and Scientific Development. 


\begin{abstract}
The main purpose of the present study was to compare the reference metabolic equivalent (MET) value and observed resting oxygen uptake $\left(\mathrm{VO}_{2}\right)$ for defining cardiorespiratory fitness $\left(\mathrm{VO}_{2 \max }\right)$ and characterizing the energy cost of treadmill running. A heterogeneous cohort of 114 healthy men volunteered to participate. In Part 1 of the study, 114 men [mean \pm SD, age: $24 \pm 5$ years; height: $177.1 \pm$ $7.9 \mathrm{~cm}$; body mass: $75.0 \pm 10.0 \mathrm{~kg}$ ] visited the laboratory twice for assessment of resting and maximal $\mathrm{VO}_{2}$ values to compare the reference MET value vs. observed resting $\mathrm{VO}_{2}$ and to investigate the association between resting $\mathrm{VO}_{2}$ and $\mathrm{VO}_{2 \max }$. In Part 2, 14 of the 114 men visited the laboratory once more to perform a 30-min bout of running at $8.0 \mathrm{~km} \cdot \mathrm{h}^{-1} / 8.3$ METs. The mean observed resting $\mathrm{VO}_{2}$ of $3.26 \mathrm{~mL} \cdot \mathrm{kg}^{-1} \cdot \mathrm{min}^{-1}$ was lower than the reference MET value of $3.5 \mathrm{~mL} \cdot \mathrm{kg}^{-1} \cdot \mathrm{min}^{-1}(P<0.001)$. Resting and maximal $\mathrm{VO}_{2}$ values relative to total body mass and fat-free mass were positively correlated $(\mathrm{R}=$ 0.71 and 0.60 , respectively; $P<0.001)$. The maximal MET and energy cost of treadmill running were consequently underestimated when calculated using the reference MET value only for those with low $\mathrm{VO}_{2 \max }(P=0.005$ to $P<0.001)$. In conclusion, the reference MET value considerably overestimated observed resting $\mathrm{VO}_{2}$ in men with low $\mathrm{VO}_{2 \max }$, resulting in underestimations of the maximal MET, exercise intensity prescription, and the energy cost of running.
\end{abstract}

Keywords: aerobic exercise; energy expenditure; resting metabolic rate; compendium of physical activities; intensity classification; cardiorespiratory fitness. 


\section{Introduction}

The metabolic equivalent (MET) has been used in various important applications relating to exercise and health, such as defining levels of cardiorespiratory fitness [17], prescribing physical exercise [11], and quantifying the energy cost of a wide variety of physical activities [1]. By convention, one MET is defined as a resting oxygen uptake $\left(\mathrm{VO}_{2}\right)$ of $3.5 \mathrm{~mL} \cdot \mathrm{kg}^{-1} \cdot \mathrm{min}^{-1}$. A potential limitation in the application of this reference MET value, is that it seems to have been derived from the observed resting $\mathrm{VO}_{2}$ of a single 40-year-old man with a body mass of approximately $70 \mathrm{~kg}[7,14,30]$. There is a growing body of empirical evidence that the reference MET value significantly overestimates mean resting $\mathrm{VO}_{2}$ in healthy adults [7,10,19]. A study involving 642 women and 127 men aged 18-74 years, for example, observed that the mean resting $\mathrm{VO}_{2}$ of $2.56 \mathrm{~mL} \cdot \mathrm{kg}^{-1} \cdot \mathrm{min}^{-1}$ was $29 \%$ lower than the reference MET value [7]. Savage et al. [27] assessed the resting $\mathrm{VO}_{2}$ in a group of 109 (60 men and 49 women) overweight individuals with coronary heart disease. The mean $\mathrm{VO}_{2}$ at rest was $2.6 \pm 0.4 \mathrm{~mL} \cdot \mathrm{kg}^{-1} \cdot \mathrm{min}^{-1}$. This value was $36 \%$ lower than the widely accepted MET value of $3.5 \mathrm{~mL} \cdot \mathrm{kg}^{-1} \cdot \mathrm{min}^{-1}$ and was similar to that reported by Byrne and Hills [6]. In another study with 125 healthy males aged 17-38 years, the mean resting $\mathrm{VO}_{2}$ of $3.21 \mathrm{~mL} \cdot \mathrm{kg}^{-1} \cdot \mathrm{min}^{-1}$ was significantly lower $(8.3 \%)$ than the standard MET value of $3.5 \mathrm{~mL} \cdot \mathrm{kg}^{-1} \cdot \mathrm{min}^{-1}$ [10]. Errors when employing the reference MET value for different practical applications are therefore likely to occur. However, the extent of such errors has not been established.

Another issue is that a large inter-individual variation in resting $\mathrm{VO}_{2}$ has been observed. Age, sex, and body composition are well-established in explaining some of this variation [3,24,29], but a factor that could help identify unexplained variance that has received little attention is cardiorespiratory fitness, as represented by the maximal oxygen uptake $\left(\mathrm{VO}_{2 \max }\right)$. Kozey et al. [19] categorized 118 men and 134 women according to quintiles of $\mathrm{VO}_{2 \max }$. The mean $\pm \mathrm{SD}$ resting $\mathrm{VO}_{2}$ of $2.7 \pm 0.28 \mathrm{~mL} \cdot \mathrm{kg}^{-1} \cdot \mathrm{min}^{-1}$ observed in the lowest $\mathrm{VO}_{2 \max }$ quintile was $18 \%$ lower than the $3.3 \pm 0.39 \mathrm{~mL} \cdot \mathrm{kg}^{-1} \cdot \mathrm{min}^{-1}$ in the highest $\mathrm{VO}_{2 \max }$ quintile, and $23 \%$ lower than the reference MET value of $3.5 \mathrm{~mL} \cdot \mathrm{kg}^{-1} \cdot \mathrm{min}^{-1}$. A limitation of this study, however, is that $\mathrm{VO}_{2 \max }$ was not directly assessed, but estimated using an equation proposed by Matthews et al. [22] based on age, height, sex, body mass, and a self-reported indicator of physical activity status. Further support for the influence of $\mathrm{VO}_{2 \max }$ on resting $\mathrm{VO}_{2}$ comes from a study that directly assessed $\mathrm{VO}_{2 \max }$ in a group of 26 highly trained cyclists with mean $\pm \mathrm{SD} \mathrm{VO}_{2 \max }$ of $70.9 \pm 1.2$ 
$\mathrm{mL} \cdot \mathrm{kg}^{-1} \cdot \mathrm{min}^{-1}[21]$. The observed mean $\pm \mathrm{SD}$ resting $\mathrm{VO}_{2}$ of $4.3 \pm 0.2 \mathrm{~mL} \cdot \mathrm{kg}^{-1} \cdot \mathrm{min}^{-1}$ was $29 \%$ higher than the reference MET value of $3.5 \mathrm{~mL} \cdot \mathrm{kg}^{-1} \cdot \mathrm{min}^{-1}$. To our knowledge, however, the relationship between directly assessed $\mathrm{VO}_{2 \max }$ and resting $\mathrm{VO}_{2}$ in a heterogeneous cohort has not been investigated.

Errors of overestimation and underestimation of resting $\mathrm{VO}_{2}$ have clear potential to influence the categorization of fitness when using the maximal MET, and determination of the energy cost of treadmill running. Hence the main purpose of the present study was to compare the reference MET value and observed resting $\mathrm{VO}_{2}$ with respect to these applications and the extent to which $\mathrm{VO}_{2 \max }$ is associated with resting $\mathrm{VO}_{2}$. We hypothesized that the resting $\mathrm{VO}_{2}$ would be lower than the standard value in individuals with low $\mathrm{VO}_{2 \max }$, therefore resulting in underestimations of the classification of fitness based on the maximal MET, exercise intensity prescription, and energy cost of running.

\section{Materials and methods}

\section{Participants}

A total of 114 apparently healthy men recruited from two university communities and fitness centers located in Rio de Janeiro, regardless of training status (i.e. physically active or sedentary), volunteered to participate in the study. Exclusion criteria were: a) use of medication influencing the cardiovascular or metabolic responses to exercise; b) smoking or use of ergogenic substances that could affect exercise performance; and c) any cardiovascular, respiratory, bone, muscle, or joint problems that could compromise the safety of physical exercise; and/or positive response to the Physical Activity Readiness Questionnaire. The study was performed in accordance with the ethical standards required by the journal [12] and was approved by institutional ethics committee board (reference 3082/2011). All participants provided written informed consent.

\section{Procedures}

In the first part of the study, 114 participants visited the laboratory on two occasions. During the first visit resting $\mathrm{VO}_{2}$ was determined, anthropometric measurements were taken, and participants were familiarized with the equipment and test protocols. On the second visit a maximal cardiopulmonary exercise test (CPET) for determining $\mathrm{VO}_{2 \max }$ was performed. The first part of the study allowed to compare the reference MET value vs. observed resting $\mathrm{VO}_{2}$ and to investigate the association between 
resting $\mathrm{VO}_{2}$ and $\mathrm{VO}_{2 \max }$. In the second part of the experiment, 14 of the total 114 participants volunteered for one additional visit to perform a submaximal exercise bout with continuous work rate. This allowed to investigate the accuracy of the reference MET value to determine the energy expenditure of the submaximal running as proposed by the Compendium of Physical Activities [1]. All running tests were performed on the same motorized treadmill (Inbramed ${ }^{\mathrm{TM}}$ Super ATL, Porto Alegre, RS, Brazil).

\section{Anthropometry}

Total body mass and height were assessed respectively by digital balance scales (Welmy ${ }^{\mathrm{TM}}$, São Paulo, Brazil) and a stadiometer graded in millimeters (American Medical do Brazil ${ }^{\mathrm{TM}}$, São Paulo, Brazil). Skinfold thicknesses were obtained at three sites (chest, abdomen and thigh) using a Lange ${ }^{\mathrm{TM}}$ compass (Beta Technology Incorporated, Cambridge, Maryland, EUA) and body density and percentage body fat were estimated using the equations of Siri [28] and Jackson and Pollock [16]. Fat mass and fat-free mass were derived from total body mass and percentage body fat values. The same experienced investigator obtained all skinfold measurements.

\section{Resting $\mathrm{VO}_{2}$ assessment}

The resting $\mathrm{VO}_{2}$ was determined in accordance with the recommendations of Compher et al. [8]: abstention of physical exercise, alcohol, soft drinks and caffeine in the $24 \mathrm{~h}$ preceding the assessment, fasting for $8 \mathrm{~h}$ preceding the assessment, and minimum effort when travelling to the laboratory. In the laboratory, the participants laid in a calm thermoneutral environment (mean \pm SD temperature, $22.5 \pm$ $1.5^{\circ} \mathrm{C}$ ) for an acclimation period of 10 -min, after which the $\mathrm{VO}_{2}$ was measured for 30-min in a supine position. The resting $\mathrm{VO}_{2}$ was taken as the average of the last 5 min of steady-state data (i.e. coefficient of variation $\leq 10 \%$ during $5 \mathrm{~min}$ ), since this time period has been previously shown to elicit a $\mathrm{VO}_{2}$ steadystate and high test-retest reliability [9].

\section{Maximal and submaximal exercise tests}

A ramp protocol was used to determine the $\mathrm{VO}_{2 \max }$. The workload increments were individualized to elicit each subject's limit of tolerance in 8-12 min [5]. The tests were considered maximal if at least three of the four following criteria were satisfied: a) maximum voluntary exhaustion defined by attaining a 10 on the Borg CR-10 scale; b) $90 \%$ of predicted $\mathrm{HR}_{\max }[220-$ age] or presence of heart rate plateau $(\Delta \mathrm{HR}$ 
between two consecutive work rates $\leq 4$ beats $\left.\cdot \mathrm{min}^{-1}\right)$; c) presence of $\mathrm{VO}_{2}$ plateau $\left(\Delta \mathrm{VO}_{2}\right.$ between two consecutive work rates of less than $2.1 \mathrm{~mL} \cdot \mathrm{kg}^{-1} \cdot \mathrm{min}^{-1}$ ); and $\mathrm{d}$ ) maximal respiratory exchange ratio $\left(\mathrm{RER}_{\max }\right)>1.10$ [15]. Based on the $\mathrm{VO}_{2 \max }$ values, observed and reference $\mathrm{MET}_{\max }$ values were calculated (i.e. observed $\mathrm{MET}_{\max }=\mathrm{VO}_{2 \max } \div$ resting $\mathrm{VO}_{2}$ in $\mathrm{mL} \cdot \mathrm{kg}^{-1} \cdot \mathrm{min}^{-1}$; reference $\mathrm{MET}_{\max }=\mathrm{VO}_{2 \max } \div$ $\left.3.5 \mathrm{~mL} \cdot \mathrm{kg}^{-1} \cdot \mathrm{min}^{-1}\right)$.

Seventy-two hours after performing the maximal CPET, a subgroup of 14 participants performed a 30min bout of running at $8.0 \mathrm{~km} \cdot \mathrm{h}^{-1}$, which is an exercise intensity equivalent to $8.3 \mathrm{METs}$ according to the Compendium of Physical Activities [1]. The treadmill grade was set at 1\%, which has been found to reflect the energetic cost of outdoor, level overground running [18]. The running bout was preceded by a 5-min warm-up at $5.5 \mathrm{~km} \cdot \mathrm{h}^{-1}$ and $1 \%$ grade. The intensity classification for treadmill running was calculated from two different methods: a) observed METs = average $\mathrm{VO}_{2}$ during exercise $\div$ resting $\mathrm{VO}_{2}$ in $\mathrm{mL} \cdot \mathrm{kg}^{-1} \cdot \mathrm{min}^{-1}$; and b) reference METs: average $\mathrm{VO}_{2}$ during exercise $\div 3.5 \mathrm{in} \mathrm{mL} \cdot \mathrm{kg}^{-1} \cdot \mathrm{min}^{-1}$. The energy cost of the running bout was calculated by the following formula: energy cost $(\mathrm{kcal})=$ intensity classification based on observed or reference METs $\times$ body mass in $\mathrm{kg} \times$ duration in hours [1]. To negate the confounding effects of the initial (fast) $\mathrm{VO}_{2}$ on-kinetics, the data for the first 3-min of the running bout were omitted from all analyses [19].

Expired gases were collected during the maximal CPET and 30-min running bout using a VO2000 analyser (Medical Graphics ${ }^{\mathrm{TM}}$, Saint Louis, MO, USA) and a silicone face mask (Hans Rudolph ${ }^{\mathrm{TM}}$, Kansas, MO, USA). The gas analysers and pneumotacograph were calibrated according to the manufacturer's instructions. Immediately prior to each exercise bout, the gas analysers were calibrated using a certified standard mixture of oxygen $(17.01 \%)$ and carbon dioxide $(5.00 \%)$, balanced with nitrogen (AGA ${ }^{\mathrm{TM}}$, Rio de Janeiro, RJ, Brazil). The flows and volumes of the pneumotacograph were calibrated using a syringe graduated for a 3 L capacity (Hans Rudolph ${ }^{\mathrm{TM}}$, Kansas, MO, USA). Heart rate was measured continuously using a cardiotachometer (RS800cx, Polar ${ }^{\mathrm{TM}}$, Kempele, Finland) and beat-bybeat data were 30-s stationary time-averaged.

\section{Statistical analyses}

All statistical analyses were performed using Statistica 10 software (StatSoft ${ }^{\mathrm{TM}}$, Tulsa, OK, USA). Descriptive sample statistics are reported as the mean and standard deviation (SD). One-sample t tests 
were used to test the null hypotheses that there were no mean differences between the MET value and observed resting $\mathrm{VO}_{2}, \mathrm{MET}_{\max }$, MET exercise intensity classification, and the energy cost of the running bout. The Pearson correlation was used to determine the relationship between $\mathrm{VO}_{2 \max }$ and observed resting $\mathrm{VO}_{2}$. In addition, the median $\mathrm{VO}_{2 \max }$ value was used as the criterion to categorize participants into low and high $\mathrm{VO}_{2 \max }$ groups to investigate the influence of $\mathrm{VO}_{2 \max }$ on the differences between the reference $\mathrm{MET}$ value and observed resting $\mathrm{VO}_{2}$ [lower $\mathrm{VO}_{2 \max }$ ( $1^{\text {st }}$ part of the study: $n=55$, $\mathrm{VO}_{2 \max }<49.9 \mathrm{~mL} \cdot \mathrm{kg}^{-1} \cdot \mathrm{min}^{-1} ; 2^{\text {nd }}$ part of the study: $n=7, \mathrm{VO}_{2 \max }<43.3 .0 \mathrm{~mL} \cdot \mathrm{kg}^{-1} \cdot \mathrm{min}^{-1}$ ) and higher $\mathrm{VO}_{2 \max }\left(1^{\text {st }}\right.$ part of the study: $n=59, \mathrm{VO}_{2 \max } \geq 49.9 \mathrm{~mL} \cdot \mathrm{kg}^{-1} \cdot \mathrm{min}^{-1} ; 2^{\text {nd }}$ part of the study: $n=7 ; \mathrm{VO}_{2 \max } \geq$ $\left.\left.43.3 \mathrm{~mL} \cdot \mathrm{kg}^{-1} \cdot \mathrm{min}^{-1}\right)\right]$.

\section{Results}

Sample descriptive statistics for age, anthropometric variables, resting $\mathrm{VO}_{2}$, and CPET outcomes are shown in Table 1. The mean observed resting $\mathrm{VO}_{2}$ of $3.26(95 \% \mathrm{CI}=3.17$ to 3.34$)$ and $3.07 \mathrm{~mL} \cdot \mathrm{kg}^{-1} \cdot \mathrm{min}^{-}$ ${ }^{1}(95 \% \mathrm{CI}=2.79$ to 3.34$)$ for the $1^{\text {st }}$ and $2^{\text {nd }}$ parts of the study were significantly lower than the reference MET value of $3.5 \mathrm{~mL} \cdot \mathrm{kg}^{-1} \cdot \mathrm{min}^{-1}$ (mean difference $=0.25,95 \% \mathrm{CI}=0.16$ to $0.32, \mathrm{t}=6.02, P<0.001$ and mean difference $=0.43,95 \% \mathrm{CI}=0.15$ to $0.70, \mathrm{t}=3.3, P=0.005$, respectively). With regard to the group with lower $\mathrm{VO}_{2 \max }$, the reference MET value of $3.5 \mathrm{~mL} \cdot \mathrm{kg}^{-1} \cdot \mathrm{min}^{-1}$ was significantly higher than the mean observed resting $\mathrm{VO}_{2}$ values of 3.01 (mean difference $=0.48,95 \% \mathrm{CI}=0.38$ to $0.59, \mathrm{t}=9.2, P<0.001$ ) and 2.67 (mean difference $=0.83,95 \% \mathrm{CI}=0.60$ to $1.05, \mathrm{t}=9.0, P<0.001) \mathrm{mL} \cdot \mathrm{kg}^{-1} \cdot \mathrm{min}^{-1}$ determined during the $1^{\text {st }}$ and $2^{\text {nd }}$ parts of the study, respectively. However, no statistically significant difference was detected between the reference MET value and observed resting $\mathrm{VO}_{2}$ values for the groups with higher $\mathrm{VO}_{2 \max }\left(1^{\text {st }}\right.$ part of the study: $P=0.842 ; 2^{\text {nd }}$ part of the study $\left.P=0.778\right)$.

\section{INSERT TABLE 1}

Figure 1 shows the relationships between $\mathrm{VO}_{2 \max }$ and resting $\mathrm{VO}_{2}$ relative to total body mass (A) and fatfree mass (B), which were strongly positively correlated in the $1^{\text {st }}$ part of the study $(\mathrm{R}=0.71, P<0.001$; $\mathrm{R}=0.60 ; P<0.001$, respectively).

\section{INSERT FIGURE 1}


Table 2 shows the MET $_{\max }$, and the exercise intensity classification and energy cost of the 30-min running bout, calculated from the reference MET value and observed resting $\mathrm{VO}_{2}$. Overall, the values for $\mathrm{MET}_{\max }$, exercise intensity, and energy cost of treadmill running were significantly underestimated when derived from the reference MET value of $3.5 \mathrm{~mL} \cdot \mathrm{kg}^{-1} \cdot \mathrm{min}^{-1}(P=0.007$ to $P<0.001)$, especially for the groups with lower $\mathrm{VO}_{2 \max }$. In the $1^{\text {st }}$ part of the study, for example, the mean difference between reference vs. observed $\mathrm{MET}_{\max }$ values increased from $8 \%$ (mean difference: 1.1 METs; $P<0.001$ ) to $17 \%$ (mean difference: 2.1 METs; $P<0.001$ ) when considering all participants vs. only the lower $\mathrm{VO}_{2 \max }$ group. In the $2^{\text {nd }}$ part of the study, the level of underestimation of the observed exercise intensity and energy cost increased substantially from $14 \%$ (mean difference: 1.3 METs; $P=0.007$ ) to $24 \%$ (mean difference: 2.6 METs; $P=0.007$ ) and $15 \%$ (mean difference: $62 \mathrm{kcals} ; P=0.005$ ) to $24 \%$ (mean difference: $101 \mathrm{kcals} ; P$ $=0.001)$ (see Table 2). Unlike the lower $\mathrm{VO}_{2 \max }$ group, there was no significant difference between the reference and observed MET intensities $(P=0.674)$ and energy cost of the treadmill running bout $(P=$ 0.679) for the higher $\mathrm{VO}_{2 \max }$ group.

\section{INSERT TABLE 2}

\section{Discussion}

The present study compared the reference MET value and observed resting $\mathrm{VO}_{2}$ for defining fitness using the maximal MET, prescribing exercise intensity, and quantifying the energy cost of treadmill running in a heterogeneous cohort of healthy men. The extent to which $\mathrm{VO}_{2 \max }$ explained variance in resting $\mathrm{VO}_{2}$ also was investigated. The main finding was that the reference MET value of $3.5 \mathrm{~mL} \cdot \mathrm{kg}^{-1} \cdot \mathrm{min}^{-1}$ overestimated resting $\mathrm{VO}_{2}$ in men with low $\mathrm{VO}_{2 \max }$, which resulted in underestimations of the maximal MET, exercise intensity prescription, and the energy cost of running.

The findings of the present study concur with previous studies $[7,10,19]$ that one MET is not equivalent to a resting $\mathrm{VO}_{2}$ of $3.5 \mathrm{~mL} \cdot \mathrm{kg}^{-1} \cdot \mathrm{min}^{-1}$ in heterogeneous adult cohorts. In fact, $74(65 \%)$ of the 114 participants in the present study had observed resting $\mathrm{VO}_{2}$ values lower than $3.5 \mathrm{~mL} \cdot \mathrm{kg}^{-1} \cdot \mathrm{min}^{-1}$. There was, however, a strong positive correlation between directly assessed $\mathrm{VO}_{2 \max }$ and observed resting $\mathrm{VO}_{2}$, meaning that overestimation errors in resting $\mathrm{VO}_{2}$ tended to mostly affect those with low $\mathrm{VO}_{2 \max }$. 
The MET system has been used in research for defining levels of fitness as MET $_{\max }$ values, particularly with respect to evaluating its prognostic value in predicting cardiovascular risk [2,23]. The $\mathrm{MET}_{\max }$ is quantified using tables of the energy cost of running based upon treadmill speed and slope and dividing by the reference MET value of $3.5 \mathrm{~mL} \cdot \mathrm{kg}^{-1} \cdot \mathrm{min}^{-1}$. The findings of the present study revealed that $\mathrm{MET}_{\max }$ was significantly underestimated in low cardiorespiratory groups when calculated from the widely accepted reference MET value. The same limitation of the MET system was reported within the context of exercise prescription, where the adoption of the reference MET value resulted in unacceptably large underestimation errors for treadmill running intensity and energy cost compared to when the observed resting $\mathrm{VO}_{2}$ was used. These errors therefore mostly affect low fitness individuals, which are the least likely to be meeting physical exercise recommendations for promoting health.

Another issue is the large inter-individual variation in observed resting $\mathrm{VO}_{2}$ identified in previous research [7,10,19], as well as the participants in the present study (see Table 1). Byrne et al. [7] reported that $62 \%$ of this variation could be explained by differences in fat mass and fat-free mass, whilst age explained only $14 \%$. Additionally, BMI was strongly positively correlated with fat mass $\left(\mathrm{r}^{2}=0.93, P<\right.$ 0.001), and the variance in resting $\mathrm{VO}_{2}$ was also well explained by a combination of BMI, age and gender. These findings were not supported by Cunha et al. [10], however, as BMI explained only $0.15 \%$ of the variance in the resting $\mathrm{VO}_{2}$ of 125 healthy men. A question therefore arises as to what additional factors might explain the unexplained variance. One factor is $\mathrm{VO}_{2 \max }$, which is thought to potentiate the energy requirements of tissue thereby increasing resting metabolic rate (RMR) and resting $\mathrm{VO}_{2}[25,26]$. Poehlman et al. [25], for example, compared the RMR and resting $\mathrm{VO}_{2}$ of 18 healthy men aged 18 to 37 yr, who were classified as either trained $\left(\mathrm{n}=9, \mathrm{VO}_{2 \max }=70.5 \pm 1.8 \mathrm{~mL} \cdot \mathrm{kg}^{-1} \cdot \mathrm{min}^{-1}\right)$ or untrained $(\mathrm{n}=9$, $\mathrm{VO}_{2 \max }=53.0 \pm 2.4 \mathrm{~mL} \cdot \mathrm{kg}^{-1} \cdot \mathrm{min}^{-1}$ ). The authors observed a higher RMR (i.e. $9 \%$ ) and resting $\mathrm{VO}_{2}($ i.e. $18 \%$ ) in the trained vs. untrained participants (i.e. 1.29 vs. $1.17 \mathrm{kcal} . \mathrm{min}^{-1}$ and $\sim 3.69 \mathrm{vs} .3 .01 \mathrm{~mL} \cdot \mathrm{kg}^{-}$ ${ }^{1} \cdot \min ^{-1}$, respectively). This effect persisted even when participants were matched for body fat content. These authors subsequently observed a strong positive correlation between $\mathrm{RMR}$ and $\mathrm{VO}_{2 \max }(\mathrm{r}=0.77$ and $P<0.01)$ in 28 healthy men, aged 19 to $36 \mathrm{yr}$, and a wide $\mathrm{VO}_{2 \max }$ range of 40 to $80 \mathrm{~mL} \cdot \mathrm{kg}^{-1} \cdot \mathrm{min}^{-1}$ [26]. Our findings concur with those studies; however, other studies reported conflicting findings $[4,13,20]$, which might be accounted for by two methodological issues: a) small sample sizes and insufficient statistical power to detect correlations between resting $\mathrm{VO}_{2}$ and $\mathrm{VO}_{2 \max }$; and b) failure to investigate a wide range of $\mathrm{VO}_{2 \max }$. Indeed, the sample sizes of 14 and 8 participants adopted by LeBlanc 
et al. [20] and Hill et al. [13], respectively, are limited for investigating associations between resting $\mathrm{VO}_{2}$ and $\mathrm{VO}_{2 \max }$. In a cross-sectional study designed to determine the relationship between $\mathrm{RMR}$ and $\mathrm{VO}_{2 \max }$, Broeder et al. [4] included 69 men exhibiting a wide range of $\mathrm{VO}_{2 \max }\left(32.8\right.$ to $\left.78.1 \mathrm{~mL} \cdot \mathrm{kg}^{-1} \cdot \mathrm{min}^{-1}\right)$. A significant positive correlation was observed between $\mathrm{VO}_{2 \max }$ and $\mathrm{RMR}$ when expressed in $\mathrm{kJ} \cdot \mathrm{kg}$ total body weight $\cdot \mathrm{hr}^{-1}(\mathrm{r}=0.68$ and $P<0.001)$, but not when expressed relative to $\mathrm{kJ} \cdot \mathrm{kg}$ fat-free mass $\cdot \mathrm{hr}^{-1}(\mathrm{r}=$ 0.04 and $P<0.75)$. In addition, there were no significant differences in RMR between high, moderate, and low $\mathrm{VO}_{2 \max }$ groups. Even so, it is feasible that the lack of a statistically significant difference in RMR between the three groups was due to the limited range in $\mathrm{VO}_{2 \max }$ between the low vs. moderate $\mathrm{VO}_{2 \max }$ groups (i.e. only $\sim 10 \mathrm{~mL} \cdot \mathrm{kg}^{-1} \cdot \mathrm{min}^{-1}$ or $19 \%\left[41.1 \pm 0.6\right.$ vs. $\left.51.0 \pm 0.6 \mathrm{~mL} \cdot \mathrm{kg}^{-1} \cdot \mathrm{min}^{-1}\right]$ ). In the present study the difference between low and high cardiorespiratory groups with respect to minimum and maximum values of $\mathrm{VO}_{2 \max }$ were $\sim 35 \%\left(32.5 \mathrm{vs} .50 .0 \mathrm{~mL} \cdot \mathrm{kg}^{-1} \cdot \mathrm{min}^{-1}\right)$ and $\sim 26 \%\left(49.7 \mathrm{vs} .67 .1 \mathrm{~mL} \cdot \mathrm{kg}^{-}\right.$ $\left.{ }^{1} \cdot \min ^{-1}\right)$, respectively (see Table 1$)$.

In conclusion, the reference MET value of $3.5 \mathrm{~mL} \cdot \mathrm{kg}^{-1} \cdot \mathrm{min}^{-1}$ overestimated resting $\mathrm{VO}_{2}$ in a relatively large group of apparently healthy men, aged 18-38 years. In a practical context, the reference MET value demonstrated relatively poor accuracy in defining fitness using the maximal MET, prescribing exercise intensity, and quantifying the energy cost of treadmill running in men with low $\mathrm{VO}_{2 \max }$, causing underestimation errors with respect to these three applications. On the other hand, minimal errors were observed in participants with high $\mathrm{VO}_{2 \max }$. Further research needs to be conducted to investigate the applicability of the reference MET value in specific populations.

\section{Conflict of Interest}

The authors report no conflict of interest.

\section{References}

1. Ainsworth BE, Haskell WL, Herrmann SD, Meckes N, Bassett DR, Jr., Tudor-Locke C, Greer JL, Vezina J, Whitt-Glover MC, Leon AS. 2011 Compendium of Physical Activities: a second update of codes and MET values. Med Sci Sports Exerc 2011; 43: 1575-1581 
2. Blair SN, Kohl HW, 3rd, Barlow CE, Paffenbarger RS, Jr., Gibbons LW, Macera CA. Changes in physical fitness and all-cause mortality. A prospective study of healthy and unhealthy men. JAMA 1995; 273: 1093-1098

3. Bosy-Westphal A, Kossel E, Goele K, Later W, Hitze B, Settler U, Heller M, Gluer CC, Heymsfield SB, Muller MJ. Contribution of individual organ mass loss to weight loss-associated decline in resting energy expenditure. Am J Clin Nutr 2009; 90: 993-1001

4. Broeder CE, Burrhus KA, Svanevik LS, Wilmore JH. The effects of aerobic fitness on resting metabolic rate. Am J Clin Nutr 1992; 55: 795-801

5. Buchfuhrer MJ, Hansen JE, Robinson TE, Sue DY, Wasserman K, Whipp BJ. Optimizing the exercise protocol for cardiopulmonary assessment. J Appl Physiol 1983; 55: 1558-1564

6. Byrne NM, Hills AP. Relationships between HR and VO2 in the obese. Med Sci Sports Exerc 2002; $34: 1419-1427$

7. Byrne NM, Hills AP, Hunter GR, Weinsier RL, Schutz Y. Metabolic equivalent: one size does not fit all. J Appl Physiol 2005; 99: 1112-1119

8. Compher C, Frankenfield D, Keim N, Roth-Yousey L. Best practice methods to apply to measurement of resting metabolic rate in adults: a systematic review. J Am Diet Assoc 2006; 106: $881-903$

9. Cunha FA, Midgley AW, Monteiro W, Freire R, Lima T, Farinatti PT. How long does it take to achieve steady state for an accurate assessment of resting VO2 in healthy men? Eur J Appl Physiol 2013; 113: 1441-1447

10. Cunha FA, Midgley AW, Montenegro R, Oliveira RB, Farinatti PT. Metabolic equivalent concept in apparently healthy men: a re-examination of the standard oxygen uptake value of 3.5 mL.kg(-1).min(-1.). Appl Physiol Nutr Metab 2013; 38: 1115-1119

11. Garber CE, Blissmer B, Deschenes MR, Franklin BA, Lamonte MJ, Lee IM, Nieman DC, Swain DP. American College of Sports Medicine position stand. Quantity and quality of exercise for developing and maintaining cardiorespiratory, musculoskeletal, and neuromotor fitness in apparently healthy adults: guidance for prescribing exercise. Med Sci Sports Exerc 2011; 43: 1334-1359

12. Harriss DJ, Atkinson G. Ethical Standards in Sport and Exercise Science Research: 2016 Update. Int J Sports Med 2015; 36: 1121-1124 
13. Hill JO, Heymsfield SB, McMannus C, 3rd, DiGirolamo M. Meal size and thermic response to food in male subjects as a function of maximum aerobic capacity. Metabolism 1984; 33: 743749

14. Howley ET. You asked for it: question authority. ACSM Health Fitness J 2000; 4: 6-8

15. Howley ET, Bassett DR, Jr., Welch HG. Criteria for maximal oxygen uptake: review and commentary. Med Sci Sports Exerc 1995; 27: 1292-1301

16. Jackson AS, Pollock ML. Generalized equations for predicting body density of men. Br J Nutr 1978; 40: 497-504

17. Jette M, Sidney K, Blumchen G. Metabolic equivalents (METS) in exercise testing, exercise prescription, and evaluation of functional capacity. Clin Cardiol 1990; 13: 555-565

18. Jones AM, Doust JH. A $1 \%$ treadmill grade most accurately reflects the energetic cost of outdoor running. J Sports Sci 1996; 14: 321-327

19. Kozey S, Lyden K, Staudenmayer J, Freedson P. Errors in MET estimates of physical activities using $3.5 \mathrm{ml} \mathrm{x} \mathrm{kg}(-1) \mathrm{x} \min (-1)$ as the baseline oxygen consumption. J Phys Act Health 2010; 7 : $508-516$

20. LeBlanc J, Diamond P, Cote J, Labrie A. Hormonal factors in reduced postprandial heat production of exercise-trained subjects. J Appl Physiol Respir Environ Exerc Physiol 1984; 56: 772-776

21. Lounana J, Campion F, Noakes TD, Medelli J. Relationship between \%HRmax, \%HR reserve, \%VO2max, and \%VO2 reserve in elite cyclists. Med Sci Sports Exerc 2007; 39: 350-357

22. Matthews CE, Heil DP, Freedson PS, Pastides H. Classification of cardiorespiratory fitness without exercise testing. Med Sci Sports Exerc 1999; 31: 486-493

23. Myers J, Prakash M, Froelicher V, Do D, Partington S, Atwood JE. Exercise capacity and mortality among men referred for exercise testing. N Engl J Med 2002; 346: 793-801

24. Nielsen S, Hensrud DD, Romanski S, Levine JA, Burguera B, Jensen MD. Body composition and resting energy expenditure in humans: role of fat, fat-free mass and extracellular fluid. Int J Obes Relat Metab Disord 2000; 24: 1153-1157

25. Poehlman ET, Melby CL, Badylak SF. Resting metabolic rate and postprandial thermogenesis in highly trained and untrained males. Am J Clin Nutr 1988; 47: 793-798 
26. Poehlman ET, Melby CL, Badylak SF, Calles J. Aerobic fitness and resting energy expenditure in young adult males. Metabolism 1989; 38: 85-90

27. Savage PD, Toth MJ, Ades PA. A re-examination of the metabolic equivalent concept in individuals with coronary heart disease. J Cardiopulm Rehabil Prev 2007; 27: 143-148

28. Siri WE. Body composition from fluid spaces and density: analysis of methods. (Vol. 9): In: Brozek J, Henschel A, editors. Techniques for measuring body composition. Washington DC: National Academy of Science. ; 1961

29. Toth MJ. Comparing energy expenditure data among individuals differing in body size and composition: statistical and physiological considerations. Curr Opin Clin Nutr Metab Care 2001; 4: 391-397

30. Wasserman K, Hansen JE, Sue DY, Whipp BJ, Casaburi R. Measurements during integrative cardiopulmonary exercise testing. In: Principles of Exercise Testing and Interpretation (2nd ed) 2nd ed: Philadephia, PA: Lea \& Febiger; 59-69; 1994 
Table 1. Mean \pm SD (range) participant characteristics.

\begin{tabular}{|c|c|c|c|}
\hline & Variable & $1^{\text {st }}$ part of study $(n=114)$ & $2^{\text {nd }}$ part of study $(n=14)$ \\
\hline \multirow[t]{21}{*}{ Anthropometric assessment } & Age - All participants $(\mathrm{yr})$ & $24 \pm 5(18-38)$ & $25 \pm 6(18-36)$ \\
\hline & Age - lower $\mathrm{VO}_{2 \max }(\mathrm{yr})$ & $25 \pm 5(18-36)$ & $30 \pm 4(23-36)$ \\
\hline & Age - higher $\mathrm{VO}_{2 \max }(\mathrm{yr})$ & $24 \pm 6(18-38)$ & $26 \pm 5(18-30)$ \\
\hline & Height - All participants $(\mathrm{cm})$ & $177.0 \pm 8.1(160.8-192.3)$ & $177.3 \pm 7.4(165.6-188.8)$ \\
\hline & Height - lower $\mathrm{VO}_{2 \max }(\mathrm{cm})$ & $177.1 \pm 7.9(160.8-192.3)$ & $177.2 \pm 10.1(165.6-188.8)$ \\
\hline & Height - higher $\mathrm{VO}_{2 \max }(\mathrm{cm})$ & $177.0 \pm 8.4(162.9-201.5)$ & $177.4 \pm 4.0(169.8-183.0)$ \\
\hline & Total body mass - All participants (kg) & $75.0 \pm 10.0(52.6-110.9)$ & $74.2 \pm 9.0(61.9-87.7)$ \\
\hline & Total body mass - lower $\mathrm{VO}_{2 \max }(\mathrm{kg})$ & $77.9 \pm 10.6(52.6-110.9)$ & $76.8 \pm 9.8(62.0-87.7)$ \\
\hline & Total body mass - higher $\mathrm{VO}_{2 \max }(\mathrm{kg})$ & $72.1 \pm 8.6(54.5-100.8)$ & $71.7 \pm 8.1(61.9-79.6)$ \\
\hline & Body mass index - All participants $\left(\mathrm{kg} \cdot \mathrm{m}^{-2}\right)$ & $23.9 \pm 2.4(19.3-33.8)$ & $23.6 \pm 2.5(19.6-28.2)$ \\
\hline & Body mass index - lower $\mathrm{VO}_{2 \max }\left(\mathrm{kg} \cdot \mathrm{m}^{-2}\right)$ & $24.8 \pm 2.6(19.3-33.8)$ & $24.5 \pm 2.7(20.6-28.2)$ \\
\hline & Body mass index - higher $\left(\mathrm{kg} \cdot \mathrm{m}^{-2}\right)$ & $23.0 \pm 1.9(19.6-27.3)$ & $22.7 \pm 2.0(19.6-24.8)$ \\
\hline & Percentage of body fat - All participants $(\%)$ & $11.1 \pm 3.7(5.0-23.2)$ & $13.2 \pm 3.2(8.5-19.3)$ \\
\hline & Percentage of body fat - lower $\mathrm{VO}_{2 \max }(\%)$ & $12.5 \pm 4.0(6.3-23.2)$ & $14.9 \pm 3.2(10.6-19.3)$ \\
\hline & Percentage of body fat - higher $\mathrm{VO}_{2 \max }(\%)$ & $9.7 \pm 2.9(5.0-20.7)$ & $11.4 \pm 2.1(8.5-15.5)$ \\
\hline & Fat-free mass - All participants $(\mathrm{kg})$ & $66.5 \pm 8.2(44.8-89.5)$ & $64.3 \pm 6.7(55.2-74.3)$ \\
\hline & Fat-free mass - lower $\mathrm{VO}_{2 \max }(\mathrm{kg})$ & $68.1 \pm 9.0(44.8-89.5)$ & $65.2 \pm 7.6(55.2-74.3)$ \\
\hline & Fat-free mass - higher $\mathrm{VO}_{2 \max }(\mathrm{kg})$ & $65.0 \pm 7.3(50.3-87.0)$ & $63.4 \pm 6.3(56.6-70.1)$ \\
\hline & Fat mass - All participants (kg) & $8.5 \pm 3.5(3.6-21.4)$ & $9.9 \pm 3.2(5.3-14.9)$ \\
\hline & Fat mass - lower $\mathrm{VO}_{2 \max }(\mathrm{kg})$ & $9.8 \pm 3.9(4.4-21.4)$ & $11.6 \pm 3.2(6.8-14.9)$ \\
\hline & Fat mass - higher $\mathrm{VO}_{2 \max }(\mathrm{kg})$ & $7.1 \pm 2.6(3.6-14.8)$ & $8.3 \pm 2.3(5.3-12.3)$ \\
\hline \multirow[t]{6}{*}{ Resting assessment } & Resting oxygen uptake - All participants $\left(\mathrm{mL} \cdot \mathrm{kg}^{-1} \cdot \mathrm{min}^{-1}\right)$ & $3.3 \pm 0.4(2.2-4.4) *$ & $3.1 \pm 0.5(2.3-3.8) *$ \\
\hline & Resting oxygen uptake - lower $\mathrm{VO}_{2 \max }\left(\mathrm{mL} \cdot \mathrm{kg}^{-1} \cdot \mathrm{min}^{-1}\right)$ & $3.0 \pm 0.4(2.2-3.9) * \dagger$ & $2.7 \pm 0.2(2.3-2.9) * \dagger$ \\
\hline & Resting oxygen uptake - higher $\mathrm{VO}_{2 \max }\left(\mathrm{mL} \cdot \mathrm{kg}^{-1} \cdot \mathrm{min}^{-1}\right)$ & $3.5 \pm 0.3(2.8-4.4)$ & $3.5 \pm 0.3(3.0-3.8)$ \\
\hline & Resting oxygen uptake - All participants $\left(\mathrm{mL} \cdot \mathrm{kg} \mathrm{FFM}{ }^{-1} \cdot \mathrm{min}^{-1}\right)$ & $3.7 \pm 0.4(2.7-4.8)$ & $3.5 \pm 0.5(2.8-4.3)$ \\
\hline & Resting oxygen uptake - lower $\mathrm{VO}_{2 \max }\left(\mathrm{mL} \cdot \mathrm{kg} \mathrm{FFM}{ }^{-1} \cdot \mathrm{min}^{-1}\right)$ & $3.5 \pm 0.4(2.2-3.9)$ & $3.1 \pm 0.3(2.8-3.5)$ \\
\hline & Resting oxygen uptake - higher $\mathrm{VO}_{2 \max }\left(\mathrm{mL} \cdot \mathrm{kg} \mathrm{FFM}{ }^{-1} \cdot \mathrm{min}^{-1}\right)$ & $3.9 \pm 0.4(3.1-4.8)$ & $3.9 \pm 0.2(3.6-4.3)$ \\
\hline
\end{tabular}




\begin{tabular}{|c|c|c|c|}
\hline \multirow{6}{*}{$\begin{array}{l}\text { Maximal cardiopulmonary } \\
\text { exercise test }\end{array}$} & Maximal oxygen uptake - All participants $\left(\mathrm{mL} \cdot \mathrm{kg}^{-1} \cdot \mathrm{min}^{-1}\right)$ & $48.4 \pm 7.3(32.5-67.1)$ & $45.6 \pm 6.8(35.3-56.6)$ \\
\hline & Maximal oxygen uptake - lower $\mathrm{VO}_{2 \max }\left(\mathrm{mL} \cdot \mathrm{kg}^{-1} \cdot \mathrm{min}^{-1}\right)$ & $42.4 \pm 4.7(32.5-49.7)$ & $40.0 \pm 3.0(35.3-42.0)$ \\
\hline & Maximal oxygen uptake - higher $\mathrm{VO}_{2 \max }\left(\mathrm{mL} \cdot \mathrm{kg}^{-1} \cdot \mathrm{min}^{-1}\right)$ & $54.3 \pm 3.7(50.0-67.1)$ & $51.2 \pm 4.1(43.6-56.6)$ \\
\hline & Maximal oxygen uptake - All participants $\left(\mathrm{mL} \cdot \mathrm{kg} \mathrm{FFM}{ }^{-1} \cdot \mathrm{min}^{-1}\right)$ & $54.4 \pm 7.6(35.4-71.2)$ & $52.4 \pm 6.6(43.7-64.2)$ \\
\hline & Maximal oxygen uptake - lower $\mathrm{VO}_{2 \max }\left(\mathrm{mL} \cdot \mathrm{kg} \mathrm{FFM}{ }^{-1} \cdot \mathrm{min}^{-1}\right)$ & $49.3 \pm 5.0(35.4-61.1)$ & $47.0 \pm 3.0(43.7-51.3)$ \\
\hline & Maximal oxygen uptake - higher $\mathrm{VO}_{2 \max }\left(\mathrm{mL} \cdot \mathrm{kg} \mathrm{FFM}{ }^{-1} \cdot \mathrm{min}^{-1}\right)$ & $60.2 \pm 4.1(53.7-71.2)$ & $57.8 \pm 4.1(51.6-64.2)$ \\
\hline
\end{tabular}

FFM $=$ fat-free mass. * Significantly lower than the reference MET value of $3.5 \mathrm{~mL} \cdot \mathrm{kg}^{-1} \cdot \mathrm{min}^{-1}(P<0.01) . \dagger$ Significantly lower than the observed resting VO for the higher $\mathrm{VO}_{2 \max } \operatorname{group}(P<0.001)$. 
Table 2. Sample mean $\pm \mathrm{SD} \mathrm{MET}_{\max }$, MET intensity, and energy cost of running computed from the reference MET value and observed resting $\mathrm{VO}_{2}$ values. The mean difference (Mean diff), confidence interval $(95 \% \mathrm{CI})$, and test statistic $\mathrm{t}(\mathrm{t}$-test) between the reference vs. observed outcomes also are included.

\begin{tabular}{|c|c|c|c|c|c|c|c|}
\hline \multirow{2}{*}{ Variable } & \multirow{2}{*}{$\begin{array}{c}\text { Sample size } \\
(n)\end{array}$} & \multirow{2}{*}{$\begin{array}{c}\text { Reference } \\
\text { Mean } \pm \text { SD (range) }\end{array}$} & \multirow{2}{*}{$\begin{array}{c}\text { Observed } \\
\text { Mean } \pm \text { SD (range) }\end{array}$} & \multicolumn{4}{|c|}{ Reference-Observed differences } \\
\hline & & & & Mean diff & $95 \% \mathrm{CI}$ & $t$-test & $P$-values \\
\hline \multicolumn{8}{|l|}{ Maximal cardiopulmonary exercise test } \\
\hline $\mathrm{MET}_{\text {max }}$ - All participants & $(114)$ & $13.8 \pm 2.1(9.3-19.2)$ & $14.9 \pm 1.7(11.2-19.7)$ & 1.1 & $0.7,1.4$ & 6.1 & $<0.001$ \\
\hline $\mathrm{MET}_{\text {max }}$ - lower $\mathrm{VO}_{2 \max }$ group & $(55)$ & $12.1 \pm 1.4(9.3-14.2)$ & $14.2 \pm 1.7(11.2-19.7)$ & 2.1 & $1.6,2.6$ & 8.8 & $<0.001$ \\
\hline $\mathrm{MET}_{\max }-$ higher $\mathrm{VO}_{2 \max }$ group & $(59)$ & $15.5 \pm 1.1(14.3-19.2)$ & $15.6 \pm 1.3(12.6-19.1)$ & 0.1 & $0.3,0.5$ & 0.6 & 0.552 \\
\hline \multicolumn{8}{|l|}{$30-$ min running bout at $8.0 \mathrm{~km} \cdot \mathrm{h}^{-1}$} \\
\hline MET intensity - All participants & (14) & 8.3 & $9.5 \pm 1.8(7.3-13.5)$ & 1.3 & $0.4,2.3$ & 3.2 & 0.007 \\
\hline MET intensity - lower $\mathrm{VO}_{2 \max }$ group & (7) & 8.3 & $10.7 \pm 1.5(9.4-13.5)$ & 2.6 & $1.6,3.6$ & 6.1 & $<0.001$ \\
\hline MET intensity - higher $\mathrm{VO}_{2 \max }$ group & (7) & 8.3 & $8.2 \pm 0.9(7.3-9.7)$ & 0.1 & $-0.5,0.7$ & 0.4 & 0.718 \\
\hline Energy cost (kcal) - All participants & $(14)$ & $302 \pm 44(241-352)$ & $354 \pm 90(237-522)$ & 53 & 17,88 & 3.1 & 0.008 \\
\hline Energy cost $(\mathrm{kcal})$ - lower $\mathrm{VO}_{2 \max }$ group & (7) & $313 \pm 49(241-352)$ & $414 \pm 82(301-522)$ & 101 & 57,145 & 5.6 & 0.001 \\
\hline Energy cost $(\mathrm{kcal})$ - higher $\mathrm{VO}_{2 \max }$ group & $(7)$ & $291 \pm 38(243-340)$ & $295 \pm 49(237-386)$ & 4 & $-20,28$ & 0.4 & 0.679 \\
\hline
\end{tabular}



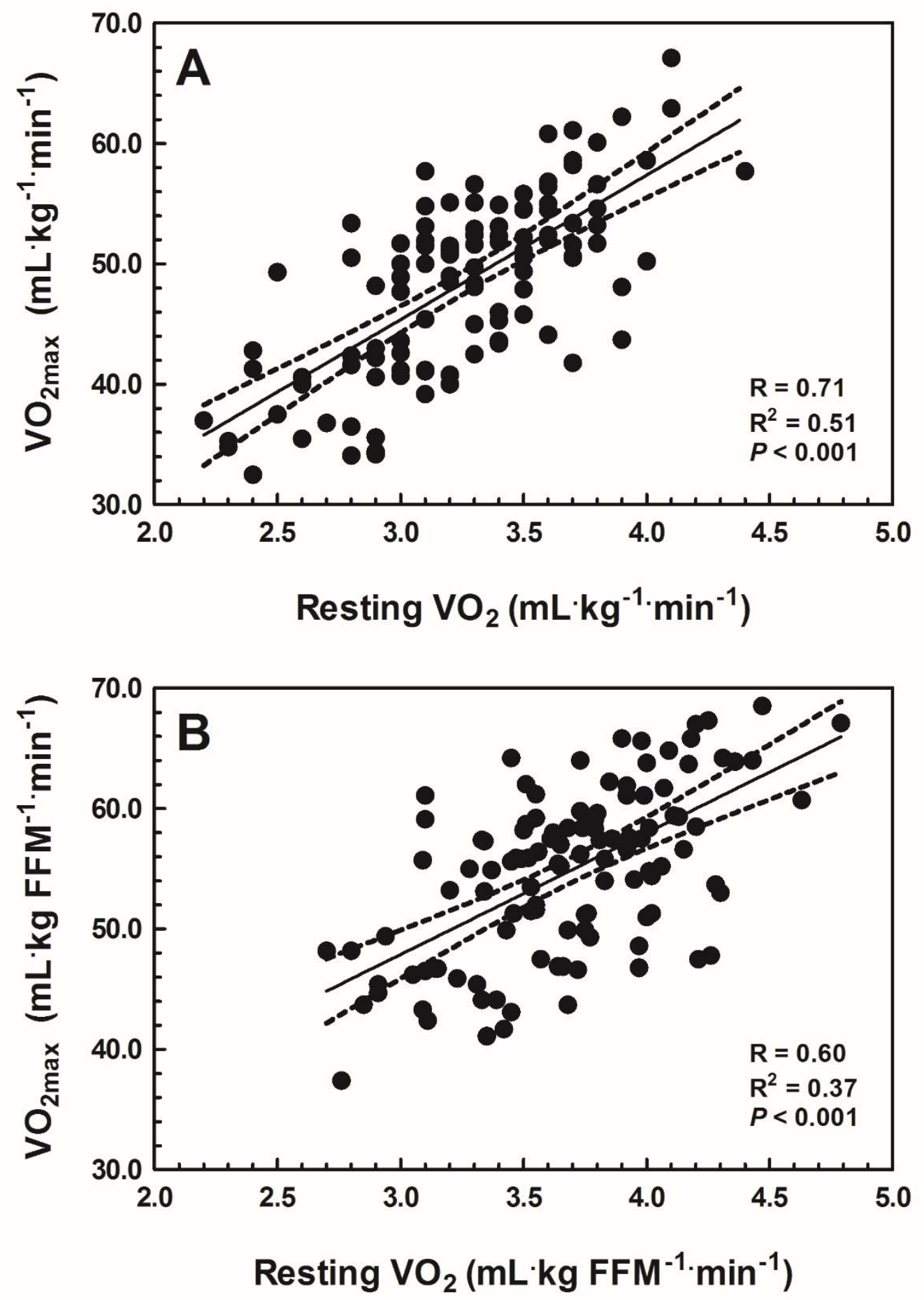

Figure 1. Relationship between maximal and resting $\mathrm{VO}_{2}$ values relative to total body mass (A) and fatfree mass $(B)$ in the $1^{\text {st }}$ part of the study $(\mathrm{N}=114)$. The dashed lines represent the 95 limits of agreement of the best-fit line. Each point represents an individual participant. Pearson correlation coefficient is given. 